\title{
Taxonomic Notes and Medicinal Uses of Two Taxa of Orchids Cymbidium devonianum Lindl. ex Paxt., and Vanda testacea (Lindl.) Rchb. f., in Darjeeling Himalaya of West Bengal, India
}

\author{
Rajendra Yonzone* \\ Directorate of Cinchona and Other Medicinal Plants, India
}

Submission: August 22, 2018; Published: October 12, 2018

*Corresponding author: Rajendra Yonzone, Directorate of Cinchona and Other Medicinal Plants, P.O. Mungpoo - 734313, District Darjeeling, West Bengal, India, Email: ryonzone99@gmail.com

\section{Abstract}

Present paper deals with brief taxonomic notes and medicinal uses of two taxa of Orchids like Cymbidium devonianum Lindl. ex Paxt. and Vanda testacea (Lindl.) Rchb. f., in Darjeeling Himalaya of West Bengal, India. Detailed description with colour photographs, digital displays, phenology, habitat, exact field status, altitudinal range, local distribution within Darjeeling Himalaya and geographical distribution are provided.

Keywords: Orchid Taxa; Cymbidium devonianum; Vanda testacea; Medicinal uses; Darjeeling Himalaya; India

Introduction

The name Darjeeling is a corruption of dorje, the precious stone or ecclesiastical scepter, which is emblematic of the thunderbolt of Sakhra (Indra) and of ling, a place and it means therefore the place of the dorje, the mystic thunderbolt of the Lamaist religion, this being the name by which the Buddhist monastery, which once stood on Observatory Hill, was formerly known [1]. By another thought, the name Darjeeling is derived from the corruption of Lepcha name Darjyu-Lyang meaning abode of the god and goddesses. The present Darjeeling town was a small market of few mat roofed houses till 1886 with the name Gundri Bazar.

Darjeeling Himalaya falls under Singalila and Chola range, the Sub-Himalayan region of Mt. Kanchanjanga and it is the northernmost hilly districts of West Bengal, India and it is the part of Eastern Himalaya with different physiographic features. They lie between 2731'05" and 2627'10" North latitude and between 8853'00" and 8759'30" East longitude. The Northern boundary commences on the West at Phalut $(3600 \mathrm{~m})$, the trijunction of the boundaries of Nepal, Sikkim and West Bengal. This boundary runs East from Phalut along the ridge descending to the Rammam river and proceeding East of that junction the boundary follows the Teesta upstream until its junction with the Rango Chu. From Phalut the Western boundary Nepal follows the Southward ridge until it joins the Mechi river upto the plains. On the South lies the district of West Dinajpur intercepted by the Mahananda river and the rest other part of the district is bounded by Bangladesh and the Jalpaiguri district. There are three Sub-Divisions in Darjeeling district viz., Darjeeling, Kurseong (hills) and Siliguri (plain) and three blocks come under Kalimpong district viz., Kalimpong, Algarah and Gorubathan (till June 2017) (Figure 1). The altitudinal variations range from $120 \mathrm{~m}$ at Siliguri to as high as $3660 \mathrm{~m}$ at Sandakphu.

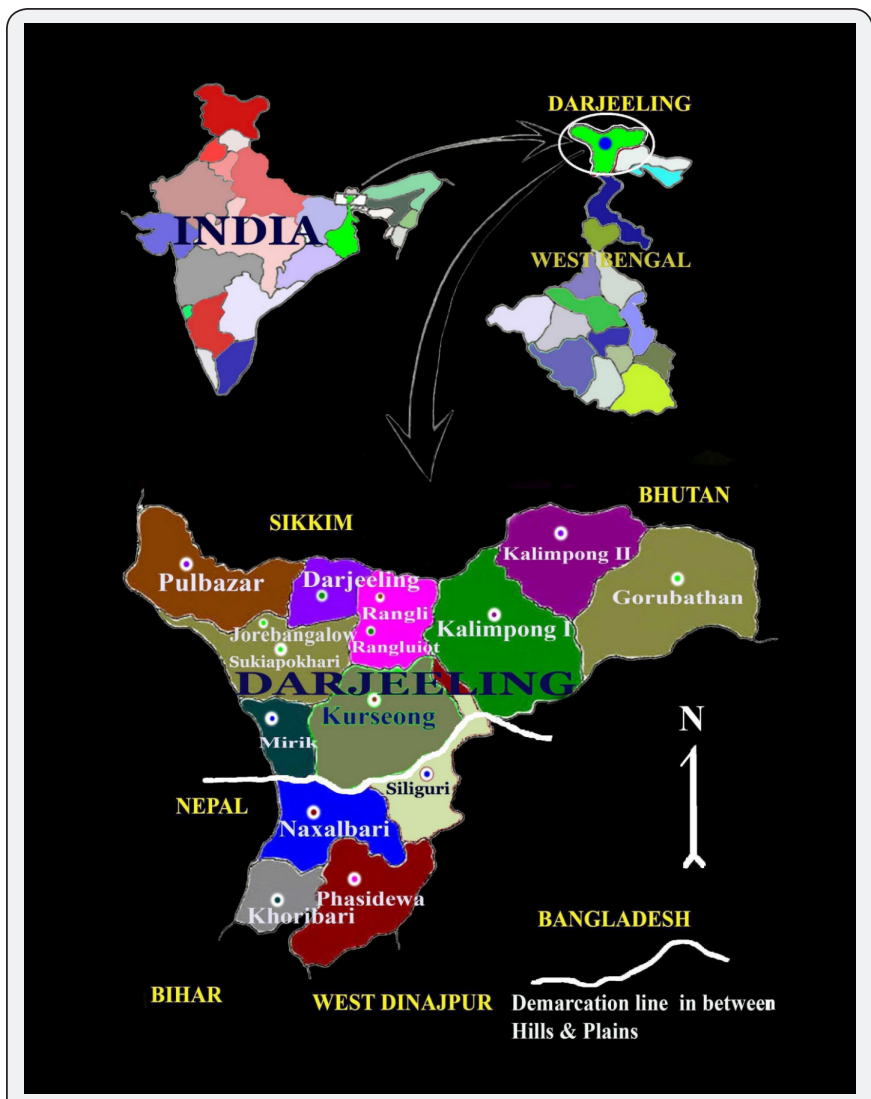

Figure 1: Location Map of Darjeeling Himalaya of West Bengal, India. 

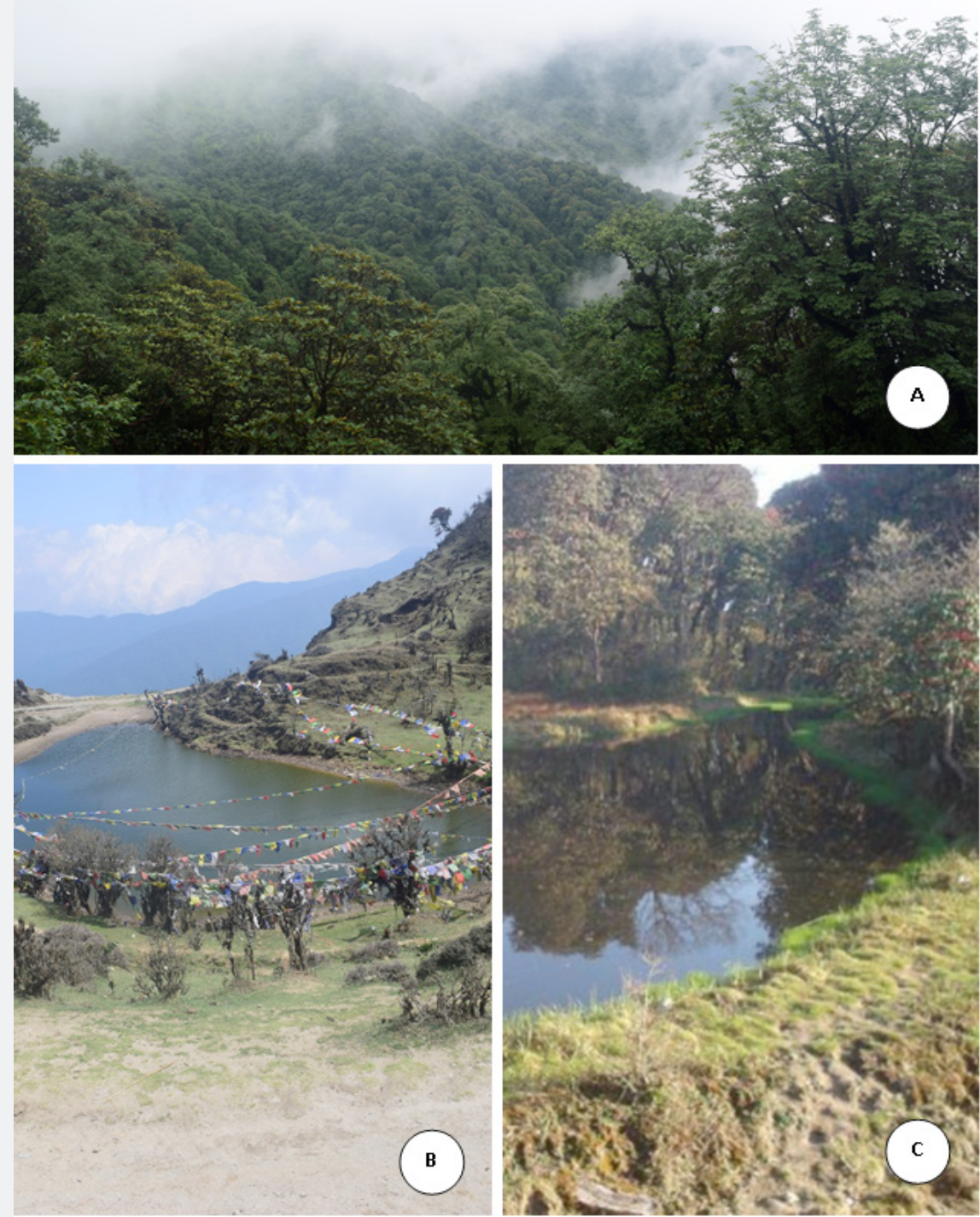

Figure 2: A) Temperate deciduous forest of Gairibas during monsoon (border area of Nepal and India),

B) Natural Lake at Kalpokhari within Singhalila National Park, Darjeeling and

C) Natural Lake at Jorepokhari within Neora Valley National Park, Kalimpong.

Vegetation of Darjeeling Himalaya is also determined by the variations corresponding to the altitudes and the vegetation of this region is classified into five categories i. Plain and Tropical vegetation, ii. Sub Tropical vegetation, iii. Sub Temperate vegetation, iv. Temperate vegetation (Figure 2, (A)) and v. Sub Alpine vegetation. The rivers and streams that originate from the Ghoom and Lava saddle however, flow northwards. The complicated network of the spurs and ridges govern the direction of the flow along different directions. The most important natural lakes include Kalpokhri, Singalila National Park (3186 m), (Figure 2(B)), two small ponds at Sandakphu (3660m) that serve as the main sources of drinking water. In the Neora Valley region of the Kalimpong Sub-Division, a pair of natural lakes Jorepokhari are located at Neora Valley National Park, Rachela (3100m), (Figure $2(\mathrm{C})$ ). Five types of rock formation are observed as we move from the South to the North in the district of Darjeeling are i. Siwalik formation, ii. Gondwana formation, iii. Buxa formation, iv. Daling formation and v. Darjeeling formation. Generally there are four different colours of soil found in Darjeeling Himalayan region viz. white clay (Kamero mato), gritty red (Lishailo mato), brown clay (Chimte mato) and black (Kalo mato). The variations of the parent materials exert a strong influence on soil characterization rather than the climate and vegetation. Depending upon the various changes in altitudinal ranges, from $120-3660 \mathrm{~m}$, the temperature also changes in great extremities from warmer to colder. This change in fact, produces a bracing and congenial climate in the upper hills. The climate (rainfall, temperature and humidity) varies from one part of the district to another corresponding to the altitudes, and configurations of different areas. Elevation wise the district is unique in having three distinct climatic zones, namely 


\section{Journal of Complementary Medicine \& Alternative Healthcare}

Tropical, Temperate and Sub-Alpine. The district has five distinct climatic seasons, namely i. Spring, ii. Summer, iii. Monsoon/Rainy, iv. Autumn and v. Winter. The area receives rainfall throughout the year, except for a short spell during the winters. Maximum rainfall is brought about by the south-west monsoon, which picks up the moisture from across the Indian Ocean and the Bay of Bengal and showers in the form of torrential rains. The district experiences highest rainfall between June to September and lowest between November to February, and moderate from March to May. The temperature of the Darjeeling Himalaya varies from place to place depending upon the altitudes. In the hilly regions the temperature (day and night) remains higher during rainy season than in the summer and spring while the range of fluctuation of temperature between the day and night is higher in the plains of Siliguri and terai region. Normally January is the coldest month and the daily temperature at Darjeeling, Sonada, Lava and Rachela often go down below $0{ }^{\circ} \mathrm{C}$. The plains are warm or hot throughout the year except a brief period during winters.

Generally rural economic condition of the Darjeeling Himalayan people is not very good and the principal livelihood of the common people of rural areas of the region had been traditional agriculture farming and at present, only $13 \%$ of the total land is utilized for agriculture purpose (Figure 3(A - F)). Very few people are engaged in commercial floriculture, horticulture, large cardamum and thysanolena latifolia plantation and floral nursery business in the region.
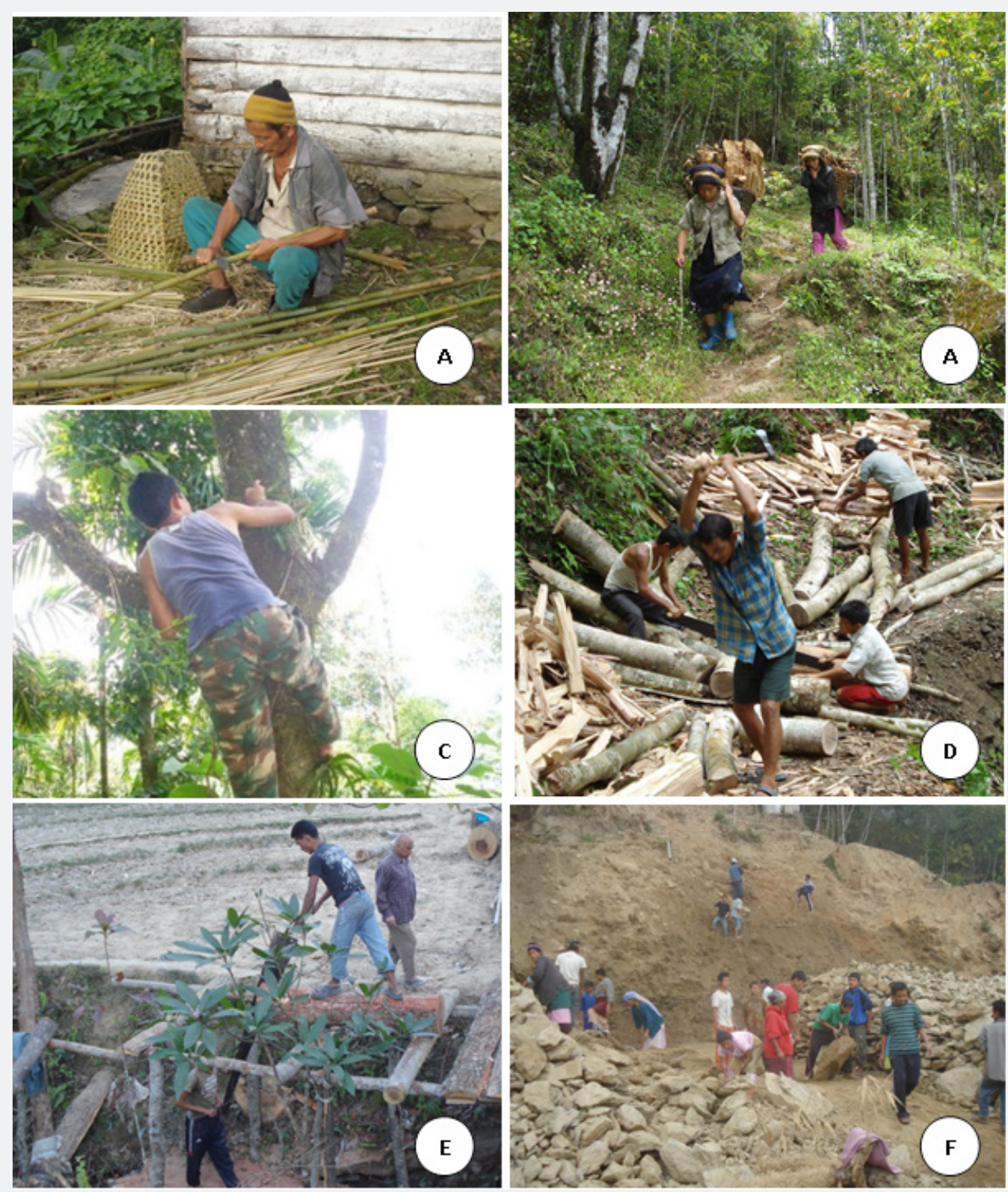

Figure 3: A) Rural livelihood, a farmer making traditional basket with bamboo strips at Kuwapani village, Kalimpong I,

B) Collection of fuel wood from forest for cooking of food, at Ramam, Darjeeling,

C) Collection of Orchid species from habitat at Chimney, Kurseong,

D) Harvesting of fuel wood by villagers at Seokbir Khani busty, Kalimpong I,

E) Harvesting of timber by villagers at Bong busty, Kalimpong I, and

F) Extension of motorable road at Lava forest of Kalimpong Block I. 
Orchids exhibit incredible diversity in colour, shape, size, structure and fragrance of flowers and four different life forms viz., epiphytic, terrestrial, saprophytic and subterranean and are pretty admired among the professional and amateur Orchid lovers of the world and are important both botanically and commercially [2] and highly evolved among the monocotyledons. Orchids are used as ornamentals, food, aphrodisiac, religious beliefs and as medicine. Orchids comprise 25000 - 30000 species distributed throughout the world [3]. In India, the Eastern Himalaya is the centre of Orchids, followed by Western Himalaya and the South Indian hills. The Khasia hills in Assam, Arunachal Pradesh and the Sikkim and Darjeeling Himalayas are richest in Orchid flora in India. Of the total Orchid species found in India nearly $70 \%$ found in North East India [4].

Some Orchid species reported to contain alkaloids, triter- penoids, flavonoids and stilbenoids. Recently, some important phytochemicals like orchinol, hircinol, cypripedin, jibantine, nidemin and loroglossin are extracted from Orchids [5]. Presence of these phytochemicals provides antimicrobial, antitumor, anti-inflammatory, antiviral activities etc. and some species used as potent inhibitor against gram positive and gram negative bacteria and some species were found to have strong antioxidative properties [6].

The medicinal importance of Orchids is known as early as 250300 BC by Susruta and Vagbhata in ancient Sanskrit literature. Ashtavarga, a group of eight drugs employed in the preparation of tonics such as Chyawanprash etc.; four species Jivak (Malaxis muscifera), Rishbhak (Malaxis acuminata), Ridhi (Habenaria intermedia) and Vridhi (Habenaria edgeworthii) are used in its preparation [7].

\section{Materials and Methods}
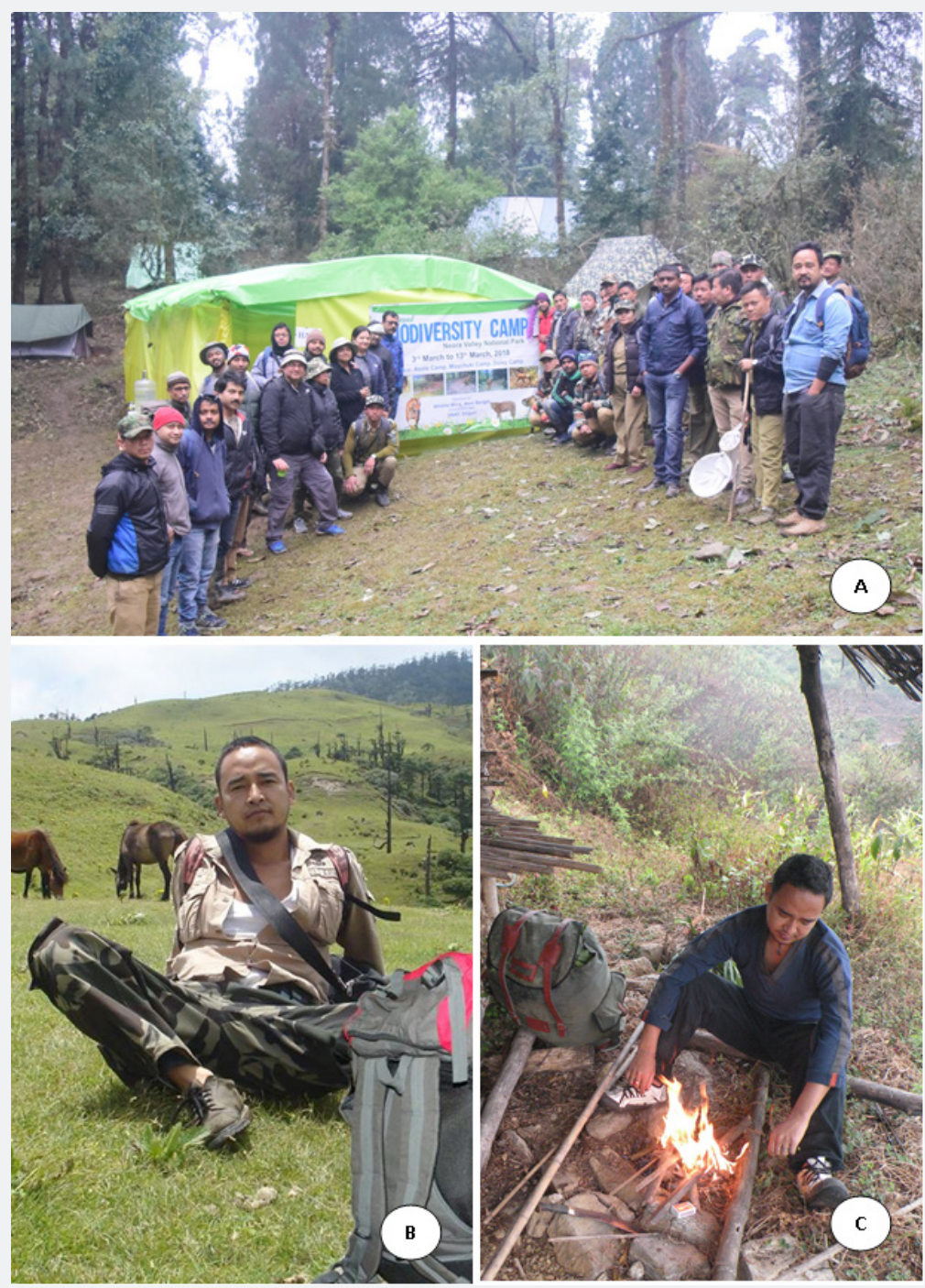

Figure 4: A) First author participated as a resource person for Orchids and Medicinal and Aromatic Plants during 10 days field survey works, i. Ashaley Camp, ii. Machuki Camp and iii. Dolley Camp at First Annual Biodiversity Camp at Neora Valley National Park, Kalimpong organize by Directorate of Forests, Govt. of West Bengal (March, 2018),

B) Taking rest during extensive field survey in between Sandakphu and Phalut, Darjeeling district of West Bengal (September, 2010), C) At cow shed of Tangta forest, near the fire during winter season. 


\section{Journal of Complementary Medicine \& Alternative Healthcare}

The intensive field survey work was started from June 2007 to March 2018 covering all the seasons of the year and far-flung villages, tea gardens, wild life areas and forests of Darjeeling Himalaya of West Bengal, India (Figure 4(A-C). The specimens were collected and properly worked out both in the field and laboratory and pressed in blotting paper. Medicinal uses of Orchid species have been done by consulting those relevant literatures including Manandhar [8]; Baral \& Kurmi [9]; Kaushik [10]; Jain [11], Hussain et al. [12] and Srivastava [13]. Some earlier workers like Bose et al. [14]; Bruhl [15]; Hara [16]; Hara [17],; Hooker [18]; King \& Pantling [19]; Ohashi [20], Pradhan [21,22]; Pradhan \& Pradhan [23]; Pearce and Cribb [24], Yonzone et al. [25-28] studied the Orchids of Darjeeling district. Recently, medicinal Orchids of the region and their uses are partially studied by workers like Yonzone et al. [29-31]; Yonzone [32-39]; Yonzone and Rai [40,41]. However, no attention has yet been given on the taxonomic notes and medicinal uses of Cymbidium devonianum and Vanda testacea from the regions in details. Therefore, present communication is aimed to provide taxonomic notes, exact field status and medicinal uses with phenology, altitudinal range, local distribution within Darjeeling Himalaya and geographical distribution of Cymbidium devonianum and Vanda testacea in details.

\section{Taxonomic enumeration}

Cymbidium devonianum Lindl. ex Paxt., Paxt.'s Mag. Bot. 10: 97 + fig. 1843.

Generic name origin from Greek word cymbi means a boat, a reference to the shape of the lip and species epithet is named after William, $6^{\text {th }}$ Duke of Devonshire, a great orchid collector and patron of horticulture.

Cymbidium sikkimense Hook. f., Fl. Brit. India 6(1): 9. 1890. [Figure 5 \& 6]

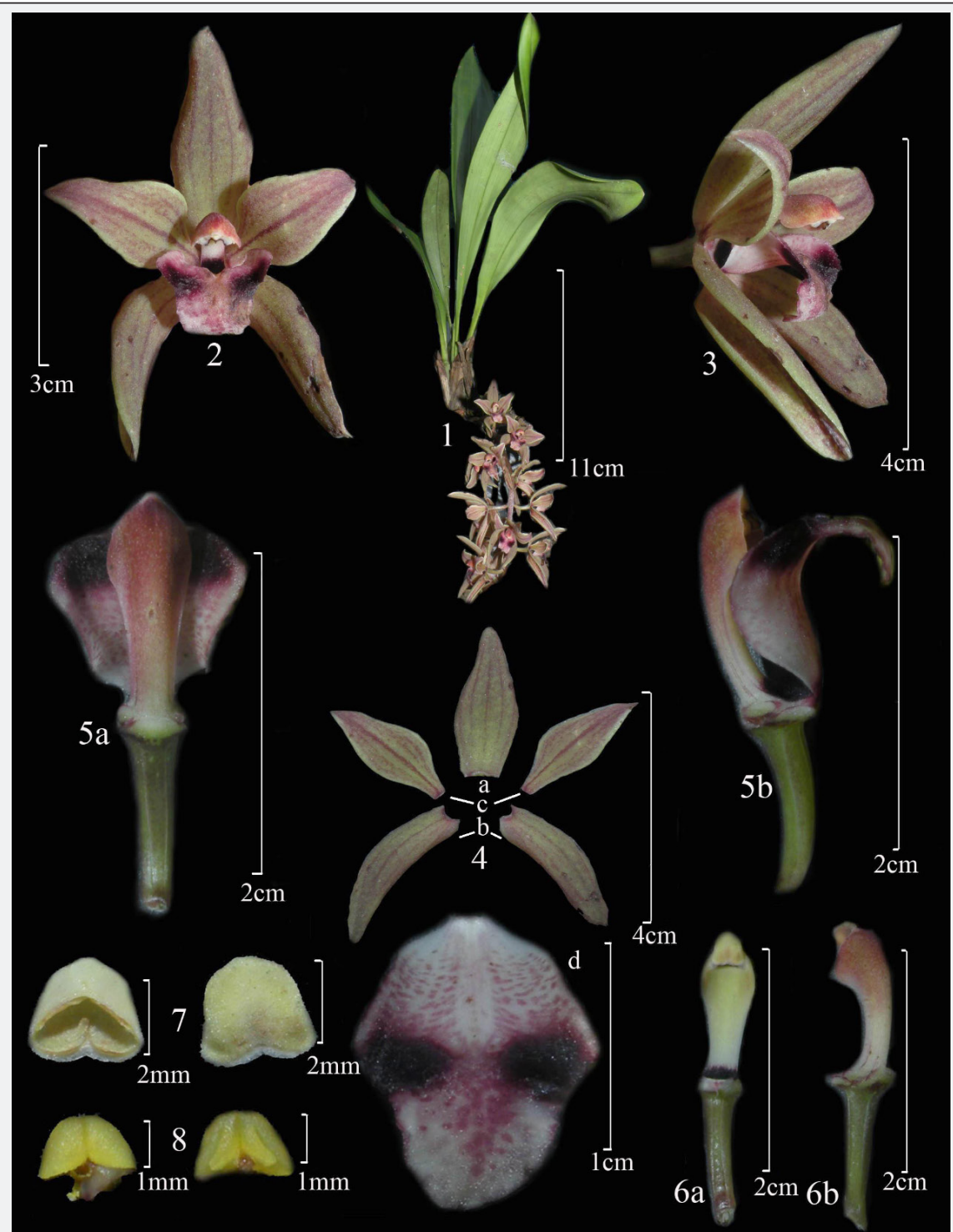

Figure 5: Cymbidium devonianum Lindl. ex Paxt., 1. Entire plant with flowering inflorescence, 2. Front view of single flower, 3 . Side view of single flower, 4. Floral perigone, a. Dorsal sepal, b. Lateral sepals, c. Petals, d. Lip, 5a. Top view of pedicellate ovary, column and lip, $5 \mathrm{~b}$. Side view of pedicellate ovary, lip and column, $6^{\text {a }}$. Ventral veiw of pedicellate ovary, column and anther, $6 \mathrm{~b}$. Side view of pedicilate ovary and column, 7 . Ventral and Dorsal view of anther and 8 . Ventral and dorsal views of pollinia. 


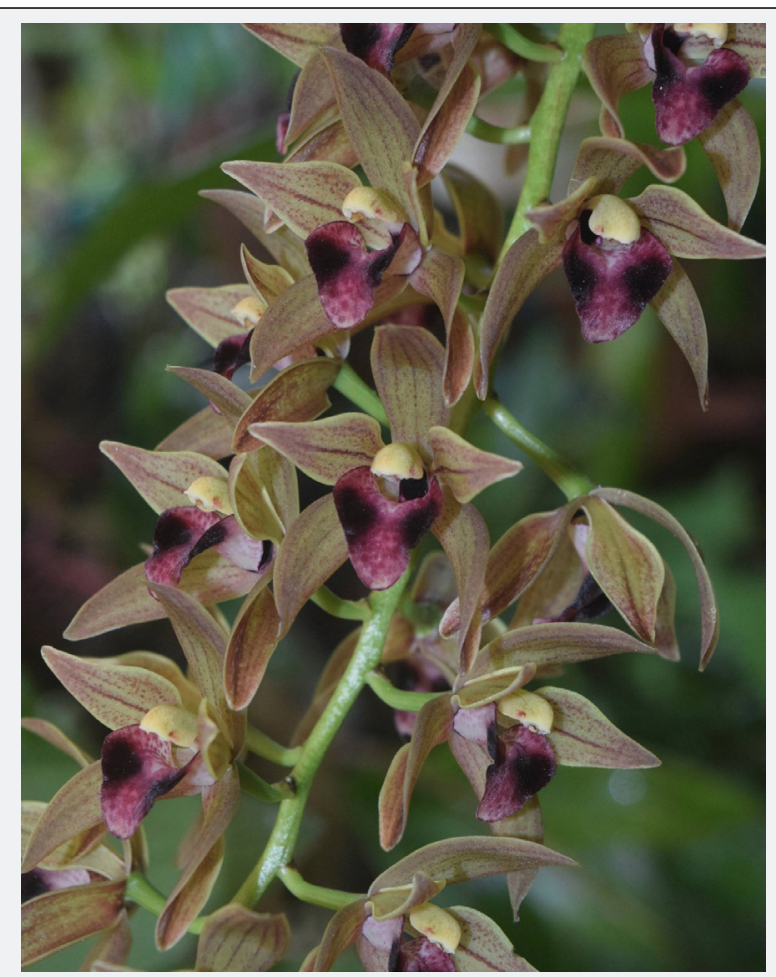

Figure 6: Cymbidium devonianum Lindl. ex Paxt., Close up view of full bloom inflorescence.

Plant epiphytic (frequently lithophytic) herb, $26-40 \mathrm{~cm}$ tall. Pseudobulbs 2-3 $\times 1.4-1.9 \mathrm{~cm}$, ovoid, sheathed. Leaves 2-4, 12$26 \times 3.2-5 \mathrm{~cm}$, elliptic, obtuse to subacute, oblique, mucronate, petiolate. Inflorescence pendent, densely 10 to 25 -flowered. Flowers $2.6-3.3 \mathrm{~cm}$ across, pale-green with dark purple nerved. Sepals subsimilar, 2-2.7 $\times 0.8-1 \mathrm{~cm}$, spreading, erect, elliptic, obtuse. Petals $1.8-2.2 \times 0.7-0.9 \mathrm{~cm}$, subquadrate, subacute to acute. Lip 1.5-1.6 × 1.1-1.4cm, slightly 3-lobed, purple with dark maroon blotch.

Habitat: Epiphytic (frequently lithophytic)

Specimen examined: India, West Bengal, Kalimpong, Toroyok busty $1690 \mathrm{~m}$.

Altitudinal range: 1300 - 2400m [42]; 1300 - 2330m [24,43].

Flowering and fruiting: April - September; Current availability status: Sparse in wild [44].

Distribution within darjeeling himalaya: Lungshel, Lava, Sukiapokhari, Damsang forest, Toroyok, Takdah, Ramam, Baggonra.

Geographical distribution: India (North East India, West Bengal); Bhutan, Myanmar, Nepal, Thailand, South China.

Vanda testacea (Lindl.) Rchb. f., Gard. Chron. n.s. 8: 166. 1877.

Generic name is derived from a Sanskrit name for certain parasitic mistletoes and species epithet is derived from the Latin word testaceus in reference to the sepals and petals.

V. parviflora Lindl., Bot. Reg. 30 (misc.): 45, 1844; Hook. f., 6: 50. 1890; King \& Pantl., 215, t. 236, 1898.

Aerides testaceum Lindl., Gen. Sp. Orchid. Pl.: 238. 1833.
Aerides wightianum Lindl., Gen. Sp. Orchid. 238. 1833. [Figure $7 \& 8]$

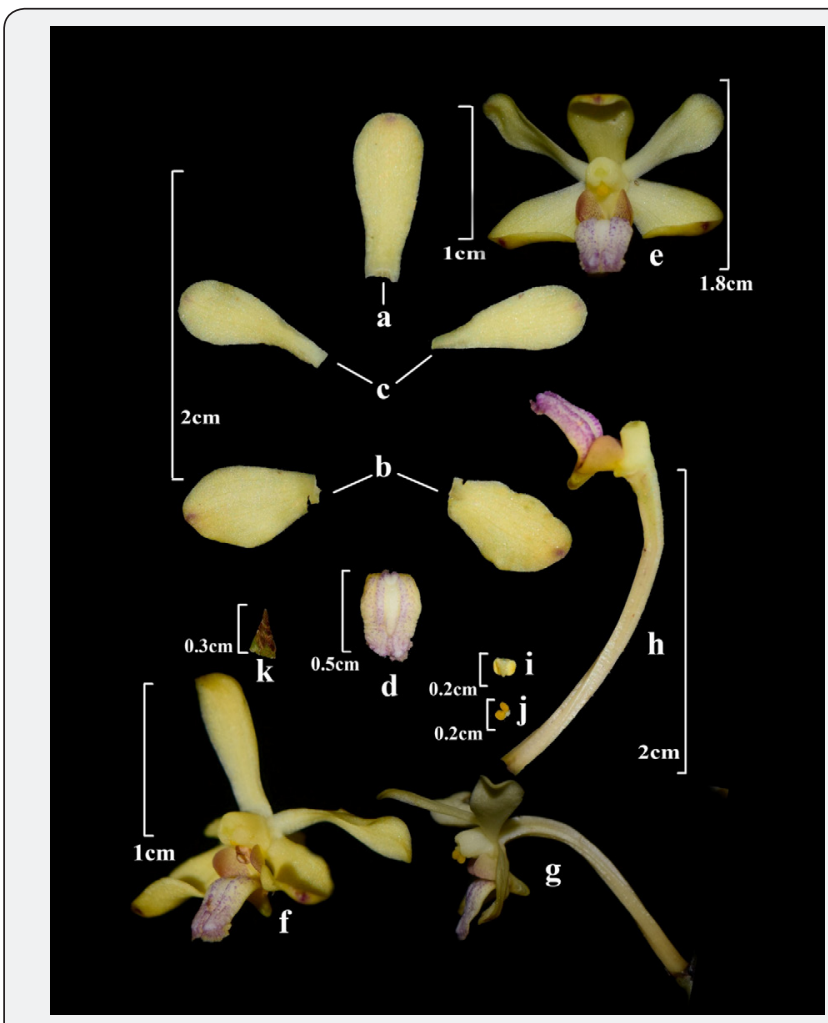

Figure 7: Vanda testacea (Lindl.) Rchb. f., Digital display of floral parts, a. Dorsal sepal, b. Lateral sepals, c. Petals, d. Lip, e. Front view of single flower, f. Angled view of flower, g. Side view of flower, pedicellate ovary with floral bract, h. Pedicellate ovary, column and lip with mentum, i. Anther, j. Pollinia, k. Floral bract. 


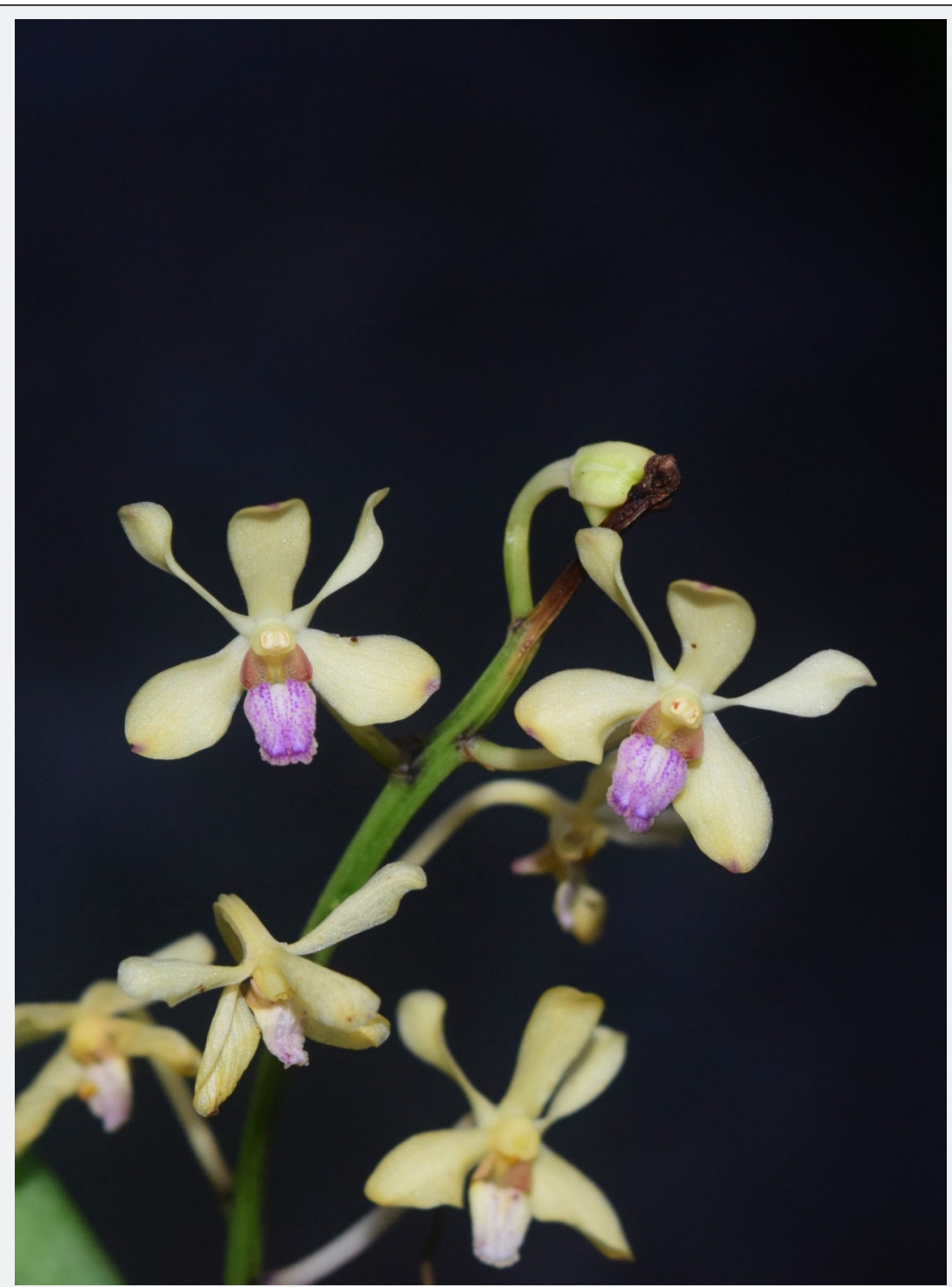

Figure 8: Vanda testacea (Lindl.) Rchb. f. (portion of inflorescence).

Plant epiphytic. Stem erect, sheathed. Leaves $8-25 \times 1.5-2 \mathrm{~cm}$, equitant, oblong, coriaceous, apex unequally 2-lobed, 3-dentate, lobules triangular to rounded. Inflorescence laxly many-flowered; peduncle stout; rachis $7-13 \mathrm{~cm}$ long. Flowers $1.9-2.1 \mathrm{~cm}$ across; sepals and petals cream-yellow, lip white, purple or reddishpink. Dorsal sepal 7-11×3-5.4mm, obovate-spathulate, obtusely rounded and incurved at apex; side sepals $5.8-9.4 \times 3-5.5 \mathrm{~mm}$, spreading, obovate-spathulate, falcate, apex rounded, incurved and twisted. Petals $6-11 \times 2.5-4.5 \mathrm{~mm}$, spreading, spathulate, concave, base narrow and twisted. Lip 3-lobed, spurred, sessile, 8-9.5mm long. Fruit long-stalked.

Specimen examined: INDIA, West Bengal, Darjeeling, Kalimpong Sub-Division, Pudung busty, 820m, 14. 05. 2016.

Altitudinal range: $750-2000 \mathrm{~m}$. Up to $1000 \mathrm{~m} \mathrm{[45];} \mathrm{Up} \mathrm{to} 1000 \mathrm{~m}$ [46]; 300-2000m [42]; 500-700m [43]; 800-2000m [47]; 100$1000 \mathrm{~m}[48]$.

Habitat: Epiphytic on tree trunks and branches of Schima wallichii.
Flowering and Fruiting: April-September;

Current availability status: Sparse in wild [44].

Distribution within Darjeeling Himalaya: Kumsi forest, Godok, Nimbong busty of Kalimpong sub-division.

Distribution within India: (Himachal Pradesh to Arunachal Pradesh), Assam, Orissa, Bihar, Madhya Pradesh, Gujarat, Western Ghats, North Kanara, Southern Peninsular India in hilly tracts, Burma and Sri Lanka [46].

Geographical distribution: Sri Lanka, India, Myanmar, China and Thailand [24].

\section{Results and Discussion}

Two taxa of medicinal orchids i.e., Cymbidium devonianum Lindl. ex Paxt. and Vanda testacea (Lindl.) Rchb. f., were reported with taxonomic notes, exact field status and medicinal uses from Darjeeling Himalaya of West Bengal. Exact field status of Cymbidium devonianum is sparse and Vanda testacea is rare and 
natural habitat of both the taxa were epiphytic but Cymbidium devonianum frequently grown also in lithophytic habitat and flowering and fruiting of both the taxa were April to September months. Root paste of $C$. devonianum applied externally to treat boils and concentrated decoction of whole plant administered orally to cure cough and cold $[8,9]$ and leaves of $V$. testacea warmed with Mustard oil and applied over swollen parts to reduce pain [10]. Leaves are used to cure cuts and wounds [11]. Leaves are used in fever; juice is introduced into the aural metus as a remedy for otitis media [12]. Root is used as antipyretic, laxative, liver and brain tonic, also used in bronchitis, dyspepsia, boils on scalp, fractures, hiccup, inflammations, lumbago, piles, secondary syphilis, diseases of the nervous system and abdomen, toothache, tremors [13].

\section{Conclusion}

Darjeeling Himalaya is the natural home of Orchid species but at present natural population of Orchid species of the region is depleting by means of deforestation, habitat destruction by multifarious anthropogenic activies like indiscriminate collection from habitat, frequent landslides, forest fire, harvesting of old host epiphytic trees for timber collection, many developmental schemes, grazing of goats and cattle etc. Therefore, Orchid sanctuaries and germplasm conservation centres should be established both in situ and ex situ conservation in the region and mass multiplication by means of micropropagation should emphasized to conserve and plantation in the suitable habitat in nature.

\section{References}

1. O’Malley LSS (1907) Darjeeling district gazetteer. Gyan Publishing House, New Delhi, India.

2. Pathak Promila, Bhattacharya A, Vij SP, Mahant KC, Dhillon K et al (2010) An update on the medicinal orchids of Himachal Pradesh with brief notes on their habit, distribution, and flowering period. J NonTimber Forest Products 17(3): 365-372.

3. Madan A, Uniyal PL, Bhatnagar AK (2013) Sustenance of Global Orchid Diversity requires understanding and simultaneous conservation of pollinators. J Orchid Soc India 27(1-2): 87-106.

4. Gogoi K, Rajendra Yonzone (2013) Orchids of the Karbi Angling district of Assam, India. The McAllen International Orchid Society Journal 14(4): 11-20.

5. De LC, Singh DR, Kumar Raj, Promila Pathak (2016) Description, production technology, and uses of some medicinal orchids. J Orchid Soc India 30: 97-101.

6. Singh S, Singh AK, Kumar S, Kumar M, Pandey PK, et al. (2012) Medicinal properties and uses of Orchids: A Concise Review 52: 11627-11634.

7. Abraham A, Vatsala P (1981) Introduction to orchids with Illustrations and Descriptions of 150 South Indian Orchids. Tropical botanical garden and Research Institute, Trivendrum, India.

8. Manandhar NP (2002) Plants and People of Nepal. Timber Press, Portland, Oregon, USA.

9. Baral SR, Kurmi PP (2006) A Compendium of Medicinal Plants of Nepal. Publisher Rachana Baral, Printed in Nepal. By Mass Printing Press, Kathmandu 7(12).

10. Kaushik P (2013) Therapeutic Value of Indian Orchids. J Orchid Soc. India 27(1-2): 37-45.
11. Jain SK (2015) Dictionary of Indian Folk Medicine and Ethnobotany. Deep Publications, New Delhi, India.

12. Hussain A, Virwani OP, Popli SP, Misra LN, Gupta MM, et al. (1992) Dictionary of Indian Medicinal Plants. CIMAP, Lucknow, India.

13. Srivastava N (2014) Medico Botany of Garhwal Himalayas. Deep Publications, New Delhi, India.

14. Bose TK, Bhattacharjee SK, Das P, Basak UC (1999) Orchids of India. (Revised edn.). Naya Prokash. Calcutta, India.

15. Bruhl P (1926) A guide to the Orchids of Sikkim. Bishen Singh Mahendra Pal Singh, Cannaught Place, Dehradun, India.

16. Hara H (1966) The Flora of Eastern Himalaya, Tokyo, University of Tokyo press, Japan.

17. Hara H (1971) The Flora of Eastern Himalaya, Second Report, University of Tokyo press, Japan.

18. Hooker JD (1888-1890) The Flora of British India. L Reeve \& Co. London Vol. 5 \& 6, UK.

19. King G, Pantling R (1898) The Orchids of the Sikkim-Himalaya. In Annals of the Royal Botanic Garden, Calcutta 8, India.

20. Ohashi H (1975) The Flora of Eastern Himalaya, Third Report. University of Tokyo press, Japan.

21. Pradhan UC (1976) Indian Orchids Guide to Identification and Culture, (Vol. I) Premulaceae Books, Kalimpong, India.

22. Pradhan UC (1979) Indian Orchids Guide to Identification and Culture, (Vol. II) Premulaceae Books, Kalimpong, India.

23. Pradhan UC, Pradhan SC (1997) 100 Beautiful Himalayan orchids and how to grow them, Premulaceae Books, Kalimpong, India.

24. Pearce NR, Cribb PJ (2002) Flora of Bhutan. The Orchids of Bhutan. Vol. 3, Part 3. Royal Botanic Garden, Edinburgh, Scotland.

25. Yonzone Rajendra, Bhujel RB, Lama D, Rai S (2012a) Orchid species Diversity of Darjeeling Himalaya of India. Int J Pharm Lif Sci 3(3): 15331550.

26. Yonzone Rajendra, Lama D, Bhujel RB, Gogoi K, Rai $S$ (2012b) Terrestrial and Semi Saprophytic Orchid species diversity of Darjeeling Himalaya of West Bengal, India. J McAllen Int Orch Soc 13(4): 2-20.

27. Yonzone Rajendra, Lama D, Bhujel RB, Gogoi K, Rai S (2012c) Diversity Resources, Distribution, Current Ecological Status of Bulbophyllum Thouars, Orchid Species in Darjeeling Himalaya of West Bengal, India. J McAllen Int Orch Soc, USA 13(10): 3-20.

28. Yonzone Rajendra, Lama D, Bhujel RB, Gogoi K, Rai S (2012d) Taxonomic Assessment on the reported Orchid species of Darjeeling district from flora of Bhutan, the Orchids of Bhutan - A review. Int J Pharm Lif Sci 3(4): 1590-1606.

29. Yonzone Rajendra, Bhujel RB, Lama D (2011) Medicinal Orchids of the Himalayan regions. Pleione. 5(2): 265-273.

30. Yonzone Rajendra, Kamran Ahsan, Bhujel RB (2012) Orchids in Ethnobotany. Proceeding volume, Int Sem Multidis Appr Angiosp Syst 2: 661-669.

31. Yonzone Rajendra, Lama D, Bhujel RB, Rai S (2013) Present Availability Status, Diversity Resources and Distribution of Medicinal Orchid species in Darjeeling Himalaya of West Bengal, India. Int J Pharm Nat Med 1(1): 14-35.

32. Yonzone Rajendra (2015) Studies on the Orchid Flora of Darjeeling Himalaya. Ph.D. Thesis. University of North Bengal, Raja Rammohunpur, Siliguri, West Bengal, India.

33. Yonzone Rajendra (2016) Exact Distributional Record of Medicinal Orchid Dendrobium chrysanthum Wall. ex Lindl., in Darjeeling Himalaya of West Bengal, India. Life Sci Bulletin 13(1): 143-144. 
34. Yonzone Rajendra (2016) Exact Distributional Record of Medicinal Orchid Dendrobium chrysanthum Wall. ex Lindl., in Darjeeling Himalaya of West Bengal, India. Life Sci Bulletin 13(1): 143-144.

35. Yonzone Rajendra (2017) Luisia zeylanica Lindl. (Orchidaceae): A less known Medicinal Orchid from Darjeeling Himalaya of West Bengal, India. Life Sci Bulletin 14(1): 48-48.

36. Yonzone Rajendra (2017) Medicinal Uses and the Exact Existence of the Epiphytic Orchid Flickingeria fugax (Rchb. f.) Seidenf. in Darjeeling Himalaya of West Bengal, India. J McAllen Int Orch Soc 18(7): 2 - 4.

37. Yonzone Rajendra (2017) Threats Assessment, Current Distributional Record, Field Status and Therapeutic Uses of Medicinally Important Bulbophyllum Thou. (Orchidaceae) from Darjeeling and Kalimpong Districts of West Bengal, India. Trends in Biosciences 10(22): 4362 4369.

38. Yonzone Rajendra (2017) Current Availability Status and Medicinal Uses of Anoectochilus roxburghii (Wall.) Lindl. (Orchidaceae) in Darjeeling Himalaya of West Bengal, India. Trends in Biosciences 10(31): 6565-6568.

39. Yonzone Rajendra (2017) Medicinal Uses and Field Status of Three additional Coelogyne Soo. (Orchidaceae) in Darjeeling Himalaya of West Bengal, India. Trends in Biosciences 10(38): 7940-7945.

40. Yonzone Rajendra, Rai S (2016) Dendrobium Diversity in Darjeeling Himalaya, Taxonomic Details with Cultivation Practices. Directorate of Cinchona and Other Medicinal Plants, Mungpoo, Darjeeling, India.

This work is licensed under Creative

Commons Attribution 4.0 License

DOI: 10.19080/JCMAH.2018.08.555733
41. Yonzone Rajendra, Rai S (2017) Medicinal orchid genera Satyrium Sw. and its exact existence in Darjeeling Himalayan regions of Eastern Himalaya. World J Pharma Res 6(2): 979-985.

42. Chowdhery HJ (1998) Orchid Flora of Arunachal Pradesh. Bishen Singh Mahendra Pal Singh, Dehradun, India, pp. 61.

43. Lucksom SZ (2007) The Orchids of Sikkim and North East Himalaya Development Area, Jiwan Thing Marg, Gangtok, Sikkim, pp. 421-442.

44. Yonzone Rajendra, Rai S (2018) Availability Status, Habit and Habitat of Some Important Medicinal Plants of West Bengal, India. Trends in Biosciences 11(12): 2319-2341.

45. Deva S, Naithani HB (1986) Orchids of North - West Himalaya. Bishen Singh Mahendra Pal Singh, Dehradun, India, pp. 226-227.

46. Pangtey YPS, Samant SS, Rawat GS (1991) Orchids of Kumaun Himalaya Bishen Singh Mahendra Pal Singh. Dehradun, India, pp. 96-100.

47. Chowdhery HJ, Agrawala DK (2013) A Century of West Himalayan Orchids. Bishen Singh Mahendra Pal Singh, Dehradun, India, pp. 108109.

48. Misra S (2014) Orchids of Odisha, A Handbook. Bishen Singh Mahendra Pal Singh, Dehradun, India.

\section{Your next submission with Juniper Publishers will reach you the below assets}

- Quality Editorial service

- Swift Peer Review

- Reprints availability

- E-prints Service

- Manuscript Podcast for convenient understanding

- Global attainment for your research

- Manuscript accessibility in different formats ( Pdf, E-pub, Full Text, Audio)

- Unceasing customer service

Track the below URL for one-step submission https://juniperpublishers.com/online-submission.php 